Ankara Üniversitesi Türk İnkılâp Tarihi Enstitüsü Atatürk Yolu Dergisi S 25-26, Mayıs-Kasim 2000 s. 159-180

\title{
Greek Or The Western Question
}

\author{
Dr. İhsan Şerif KAYMAZ*
}

\section{ÖZET}

Türkiye ile Yunanistan arasındaki iliskileri uzun yıllardır çözülemeyen sorunlar şekillendirmektedir. Nesnel olarak tahlil edildiğinde, bu sorunların temelinde Yunanistan'ın Türkiye'ye karşı düşmanca ve yayılmacı bir politika izlediği gerçeğinin yattı̆̆ı görrülür. Maddî ve insansal kaynakları bakımından Türkiye'nin yanında çok küçük bir güç olan Yunanistan'ın bu saldırgan politikayı sürdürme cesaretini nereden bulduğu sorgulanmaya değer.

Bu sorunun yanttı, Yunanistan'ın Batı dünyası içindeki konumunu irdelememizi gerektirir. Batı'da Yunanlıların aynı adlı eskiçă̆ uygarlığının yaratıcıları ve mirasçıları olduklarına iliş̧kin yaygın bir inanç vardır. Bu bütünüyle yanlış bir inançtır. Coğrafi yakınlığı nedeniyle Yunanistan'ı Türkiye'ye karşı kullanılabilecek bir silah olarak değerlendiren Batı, elindeki silaha, ona güç kazandıracak bazı hayalî nitelikler katmayı uygun bulmuştur.

Yunanlılar, 400 yıl boyunca Osmanlı yönetimi altında özerk bir millet olarak yaşadıktan sonra 1829'da bağımsızlıklarını kazandılar. Ancak bu, Yunan halkının verdiği ulusal savaşımın değil, Batı'nın Osmanlı İmparatorluğu ïzerinde uyguladı̆̆g baskının sonucunda kazanılmış bir bağımsızlıktı. 19. ve 20. yüzyıllar boyunca Yunanistan, Batı'nın Yakın Doğu'ya yönelik emperyalist hesaplarının gönüllü bir ajanı olarak işlev gördü. Bu hizmetinin karşılığında da, geniș toprak kazanımlarıyla ödüllendirildi. Bağımsızlığını kazandıktan sonra, Osmanlı İmparatorluğu karşısında topraklarını iki katından fazla genişletti. Bu toprak kazanımlarının hiçbirisi savaş alanlarında elde edilen askerî başarıların sonucu değildi. Bunlar da, tıpkı bağımsızlığın kazanılması gibi, Batı tarafından ona bahședilen birer lütuftu.

Yunan yayılmacılığının kuramsal temelini Megali Idea denilen emperyalist bir tasarım oluşturmaktadır. 1844'te Yunan Başbakant Jean Kolettis Yunanistan't, "Yunan tarihiyle ve trkılla bağlantılı tüm topraklart içeren bir ülke" olarak tanımlamış ve bu ülkenin sınırlarının Trabzon ve Adana'ya dek uzandığını ileri

\footnotetext{
'Çanakkale Onsekiz Mart Üniversitesi, Fen-Edebiyat Fakültesi Öğretim Görevlisi.
} 
sürmüştü. Yunanistan, kısa tarihi boyunca, özellikle Türkiye'de belirsizlik ve istikrarsızlık ortamının egemen olduğu dönemlerde, durumdan yararlanarak bu akıldışı politikasını yaşama geçirmeye çalıştı. Elbette her zaman Batılı velînimetlerinin yardım ve desteğiyle. Genellikle başvurduğu yöntem, yapay sorunlar ya da oldu-bittiler yaratıp, bunları Batı'nın denetimindeki uluslararası kuruluşların ve örgütlerin gündemine taşıyarak süreç içinde adım adım amacına ulaşmaktır. Bu, uzun vadeli ve hesapll bir politikadır. Anadolu serüveninin 1922'de ağır bir felâketle sonuçlanmış olması onu yolundan döndürmemiştir. Tersine, özellikle 1981 yılından sonra, Avrupa Birliği'ne tam üye olmantn verdiği güvenle, Yunanistan'ın daha fütursuzca hareket etmeye başladığını görüyoruz. Yunan Başbakanı Andreas Papaandreu'nun 1980'li yıllarda Ege Denizi'ni bir "Yunan Denizi", Kıbrıs'ı ise bir "Yunan Adası" olarak niteleyen sözleri bu fütursuzluğun en dikkat çekici örnekleridir.

Aslına bakılırsa, bu akıldıșı politikanın arkasında yatan temel etken korkudur. Yunanistan, Batı'nın desteğiyle, kendi gücüyle asla elde edemeyeceği ve denetleyemeyeceği sınırlara ulaşmıştır. Sahip olduğu toprakların büyük bir bölümü tarihsel, kültürel ve stratejik olarak komşularının üzerlerinde hak iddia edebilecekleri topraklardir.

Tarih boyunca olduğu gibi bugün de, Türkiye ile Yunanistan arasındaki sorunlarda, ki bunların başında Kıbrıs Adası ve Ege Denizi ile bağlantıl sorunlar gelmektedir, Batı etkin bir biçimde Yunanistan'ı desteklemektedir. Çünkü Batı, Türkiye'nin, bulunduğu bölgede başat güç durumuna gelmesini istememektedir. Kendisi için çok büyük stratejik öneme sahip olan bir bölgede Türkiye'nin geçmişte olduğu gibi yeniden ön plana çıkmasını bir tehlike olarak görmektedir. Bu yüzden elindeki tüm araçlarla Türkiye'yi denetim altında tutmaya çalışmaktadır. Yunanistan bu araçlardan yalnızca birisidir. Türkiye ile Yunanistan arasındaki sorunlar, aslında Türkiye ile Batı arasındadır. Türkiye, "Batılılaşma"yı temel siyasal ve stratejik tercih olarak benimsediği için bu gerçeği görmezlikten gelse de, durum budur.

Türkiye, Batı ile bütünleşerek, kendisini Batı'dan gelen sistemli saldırılarından koruyabileceğini ummaktadır. 1920'li ve 1930'lu yıllar bir yana bırakılacak olursa, Tanzimat'tan bu yana Türk diş politikasının ana eksenini oluşturan bu yaklaşımın gerçekçi temellere dayandığını söylemek olanaklı değildir. Türkiye'yi -haklı olarakbünyesine yabancı bir varlık olarak gören Batı, bu bütünleşmeye direnmektedir. Türkiye'nin, Batı ile ilgili tüm stratejik hesaplarını gözden geçirmesi kendisi açısından bir gerekliliktir.

\section{ABSTRACT}

In the article below, Turco-Greek relations are considered on the axis of Aegean Problems. Attention is called to the fact that the real parties of those problems are Turkey and "the West" ; not Turkey and Greece. Because, Western position against the Turco-Greek conflict has always been one sided. "The West" unconditionally 
favoured Greece against Turkey. The word "West" in this context, is used to express the countries settled on each side of North Atlantic Ocean in which liberal democrasies and market economies are in force.

In the first, the historical backround of Turco-Greek relations and the Cyprus Problem are summarized. Then, the problems related to the Aegean Sea are shortly examined. In conclusion, a general comment is made on Turkey's strategic priorities.

\section{INTRODUCTION}

The relationship between Turkey and Greece is one that reflects longstanding difficulties. If analyzed objectively, it will soon be noticed that these difficulties arise mainly from the antagonistic and expansionist character of the policy pursued by Greece. This is a most astonishing fact since it is obvious that Greece is a relatively small power when compared to Turkey. She is one-sixth of Turkey in population and area, one-third in military power and less than a half in economic capacity. In her short history Greek fought two times with Turkey against whom she suffered humiliating defeats. So it is well worth asking how dare she continues to behave in such an agressive manner.

A clear understanding of Greek attitude calls for an answer to the fundamental question of her position in the Western World. In the West, Greeks are believed to be the hereditary successors of the ancient civilization of the same name; a total misapprehension that benefited Greece a lot. Besides, because of her geographical proximity, she has always been used as a weapon against Turkey by the West. As a result, Greece always happen to be one of the main sources of anxiety for Turkey.

The aim of this essay is to discuss the Greek Question in the Turkish foreign policy.

\section{HISTORICAL BACKGROUND}

After they had lived under Ottoman rule as a religiously autonomus millet for over 400 years, Greeks declared their independence in 1829. This independence however, was a product of the pressure put on the Ottoman Empire by great powers, rather than the struggle made by Greeks themselves with a national orientation. Greeks did appreciate this favor and became a voluntary agent of the Western imperialistic designs towards the Near East througout the 19th and 20th centuries. In return of their service, they had been rewarded with wide territorial grants. After taking her place in the international community as a newly founded state, the small kingdom had expanded her borders more than twice against the Ottoman Empire in less than a century. (See Map-1) It is noteworthy that none of the territorial gains 


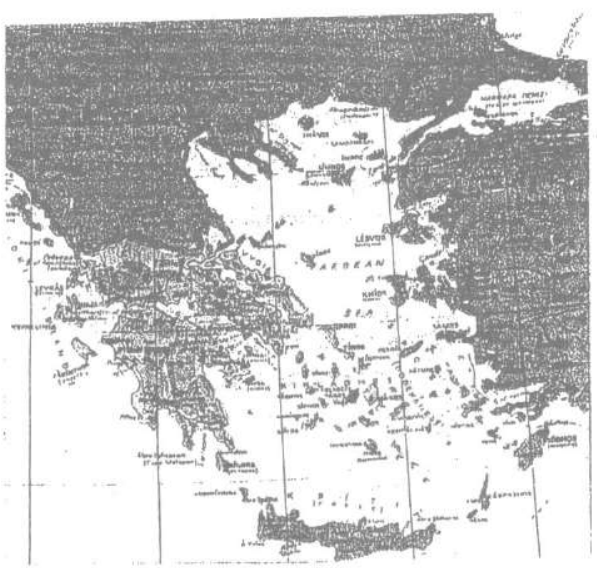

1030 - London Protocol

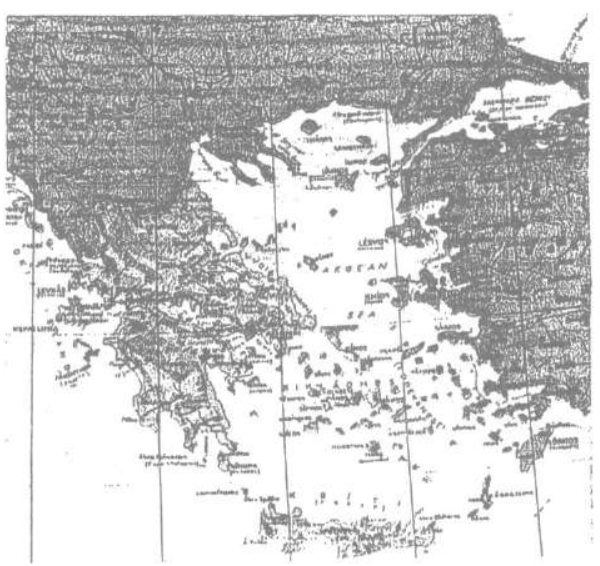

1097 - Txonty of Ist:mixu?

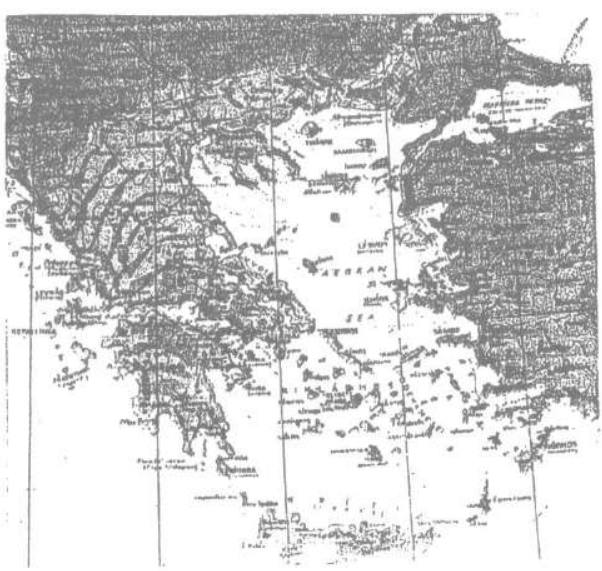

1923 - Treaty of Lausanie

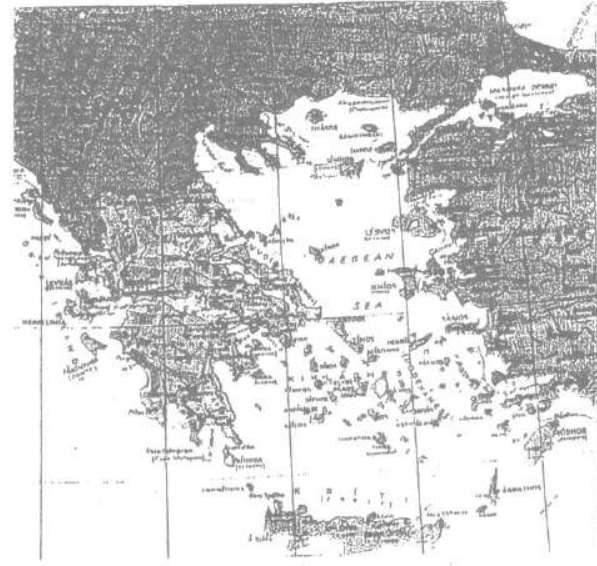

ion1 - Trenty of Istaning I

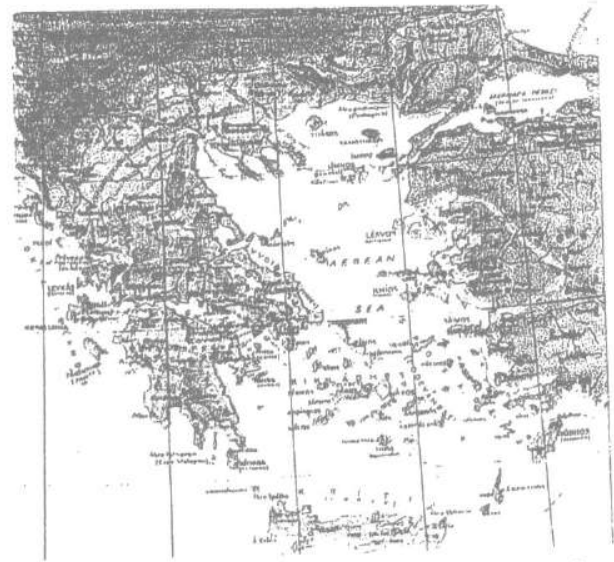

1912 - 1922 Treaty of Lon:or, Treat; of

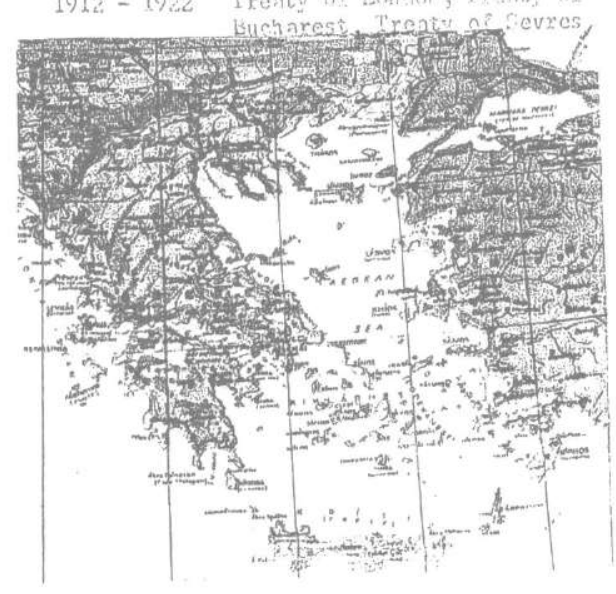

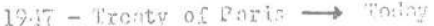

Map-1 Greek Expansion (1980-1994) 
of Greece was an outcome of her military achievements. On the contrary, she gained them generally after being defeated on the battle-ground.

Greek foreign policy depends upon an imperialistic principle called the "Megali Idea" which constitutes the theoretical basis of her expansionism. The concept has not a clear and determined definition. Since Nineteenth Century, it has either been used to express "independent Greece" or "Byzantium Empire" or "an empire under Grecian culture." Thus, it is obscure in meaning, contents and geographical limits. The concept is attributed to the Greek prime-minister Jean Kolettis. In a speech he made at the Greek parliament in January 1844 Kolettis defined Greece as "a country including all the peoples and territories related to the Greek history and race." In this connection he stated that the borders of Greece should be expanded up to Trabzon and Adana.' The main target of such an expansionist policy with respect to the definition made by Kolettis had been obviously the Ottoman Empire then and would be the Republic of Turkey as its successor afterwards.

Greece devotedly engaged herself to reach the targets of this irrational policy. Especially in times when the domestic issues in Turkey goes into a period of uncertainity and unstability or when Turkey faces some kind of occasional difficulties she instantly begins to take steps in accordance with her so-called policy. Her method is to create and manipulate some artificial problems by establishing fait accomplis and carrying them to the agenda of international organizations under Western domination where she hopes to be adventageous against Turkey. In order to reach her targets she doesn't hesitate to employ all forms of destructive activities including terror. ${ }^{2}$

Her Anatolian adventure having ended ignominiously in 1922, Greece was forced to give up her expansionist policy for some 30 years during which a relatively close and friendly relationship had been established between Turkey and Greece. This period however, ended by mid 1950's when Britain decided to decolonise the Island of Cyprus. Since then, a number of complicated problems have come into being causing the two neighbouring states recede from each other continuously. These problems are,

a) Cyprus problem,

b) Problems related to the Aegean Sea,

c) Humanitarian rights of the Turkish minority living in Greece,

d) Problem of the Patriarchate.

' Şükrü Sina Gürel, Tarihsel Boyut Içinde Türk Yunan İlişkileri (1821-1993), Ankara, Ümit Yay., 1993, p. 30.

${ }^{2}$ Suat Bilge, "Atina, Ankara, Lefkoşa Üçgeni," Cumhuriyet, 18.2.1996, p. 2. 
In 1981 the Panhelenic Socialist Activity Party under Andreas Papaandreu came into power in Greece. With Papaandreu, Greek irrationality has reached to its peak. The new Greek prime-minister with the confidence of his country's becoming a full member ofthe E.U. -then the E.E.C.- defined the Aegean Sea as a "Greek Lake" and Cyprus as a "Greek Island."

It can be said that, in the historical process the "Megali Idea" policy of Greece has been partly succesful under the auspieces of the West. So, taking the Western support as a constant, Greece is likely to go into new adventures in the future.

But on the other hand, this policy caused Greece to suffer a humiliating defeat in Anatolia and to loose nearly all her community in İstanbul, Anatolia and the other parts of the Middle East. As a result, 160 years after Kolettis, Greece has lost "the peoples and territories" which were once "related to the Greek history and race." So today, different from that of the Kolettis' time, the term "Megali İdea" has no material base.

The underlying motive of Greece's pursuing such an unreasonable policy is nothing else but fear. Anyone who looks at the map, can see the basis of this fear. Greece, having been backed up by the Western powers reached to the boundries beyond her capacity. Northern Epirus, Macedonia and the Western Thrace are the territories on which the neighbouring countries have a potential claim. As for the Aegean Sea, the closest islands to the Anatolian coasts having great strategical importarce for Turkey are under Greek posession. As long as the Western support continues there is no problem. But what will happen if the conditions are changed? It will indeed be frightening for Greece to face the answer of this question.

\section{THE MAIN PROBLEMS}

\section{A. CYPRUS ${ }^{3}$}

Cyprus lies 40 miles from the coast of Turkey and 250 miles from the nearest Greek island (Rhodes). There are two peoples living on the island, the Turkish Cypriots numbering about 200.000 and the Greek Cypriots numbering about 500.000. It has never been a part of the Greek state, whereas the Turks ruled the island for over 300 years. Turkish sovereignty on Cyprus ended officially in 1923. Then the island became a British colony, but this period lasted only 30 years. By mid 1950's Britain was forced to withdraw from Cyprus.

The negotiations in Zurich and London preceding independence were long and difficult but it was eventually agreed by way of compromise between all five participants; Britain, Greece, Turkey, the Turkish Cypriots

\footnotetext{
${ }^{3}$ T.C. Dışişleri Bakanlığı, Enformasyon Dairesi Başkanlığı, "Cyprus Breefing Note."
} 
and the Greek Cypriots. Independence was formerly gained on 16th August 1960. It became clear very soon after independence that the Greek Cypriots did not intend to abide by the constitution and that their entry into that solemn legal obligation with the Turkish Cypriots and the Guarantor Powers in 1960 had been a deception.

At Christmas 1963 the Greek Cypriot militia attacked Turkish Cypriot communities across the island and very many men, women and children were killed. 270 of their mosques, shrines and other places of worship were desecrated. Thereafter, Turkish Cypriot MP's, judges and other officials were intimidated or prevented by force from carrying out their duties. The Turkish Cypriots were forced to withdraw into defended enclaves thus they had become refugees in their own land. In 1963, 1964 and 1967 new civilian massacres targeted the Turkish Cypriots. In June 1967 the Greek Cyproit legislature unanimously passed a resolution in favor of Enosis which means to annex Cyprus to Greece.

The rest of the world has put political expediency before principle and failed to condemn this appalling behaviour. Greek Cypriots are guilty of attempted genocide but no action has ever been taken against them. Instead they have been rewarded by recognition as the government of all Cyprus. The Turkish Cypriots by contrast were frozen out of the U.N. and almost every other organization and were not allowed to be heard when many important decisions affecting their future were made.

The United Nations, not only failed to condemn the usurpation of the legal order in Cyprus by force, but actually rewarded it by treating the by then wholly Greek Cypriot Administration as if it were the government of Cyprus. (U.N. Security Council Resolution 186 of 1964.)

In 1971 General Grivas returned to Cyprus to form EOKA-B which was committed to making Cyprus a wholly Greek island annexing it to Greece. By 15th July 1974 EOKA-B supporters withdrew Makarios and installed Nicos Sampson as "president." On 20th July 1974 Turkish Army landed the island. Turkey exercised her right of intervention in accordance with article 4 of the Guarantee Treaty of 1960 . More massacres of Turkish Cypriots took place during the operations of the Turkish troops.

In 1975 Turkish Cypriots formed their own government under the leadership of Rauf Denktaş. Turkey instantly recognized the new government. But the rest of the world as a result of the Western hinderance abstain from recognizing this new political entity. A series of negotiations were held between 1975 and 2002. Before 1981, ground for meaningful negotiations which would lead a comprehensive settlement seemed to be prepared between Denktaş and Makarios. But when Greece became a full member of the E.E.C. (E.U.) things changed dramatically for Turkish Cypriots. It is obvious that Europe played a negative role on the solution of 
the problem. Taking the full support of E.U. behind them, Greece and the Greek Cypriots gave no respond to the conciliatory ouvertures of Denktaş for over 20 years.

In 2002 a new and more dramatic turning point was reached in Cyprus. Turkey have been stressing at every opportunity and at all levels that if the membership of Greek Cypriot Administretion to the E.U. is realized, it will have adverse ramifications on peace and tranquility both on the island and the Eastern Mediterranean region and that due to her historical and treatybased rights and interests Turkey would never accept this. Nevertheless, the E.U. disregarded all the warnings of Turkey and decided to take the Greek Cypriot Administration as a full member representing the whole Island of Cyprus. This encouraged the Greek Cypriots to distance themselves more and more from the negotiation process and to maintain their intransigent attitude.

United Nations on the other hand, acted as a blind instrument of the E.U. and the U.S.A. forcing Turkey to come to terms with Greece and let Cyprus become a Greek Island as wished by the Western powers. This is the resume of the so-called "Annan Plan."

\section{B. PROBLEMS RELATED TO THE AEGEAN SEA ${ }^{4}$}

Aegean Sea is an island-dotted extension of the Mediterranean Sea. It is located between Turkey and Greece with an area of 214.000 square kilometers 10 percent of which is covered with islands. (See Map - 2) Today several interrelated problems in the Aegean Sea exist between Turkey and Greece most of which were inherited from the past and yet to be resolved despite all efforts.

Lausanne Peace Treaty tried to establish a balance between Turkey and Greece by harmonizing the vital interests and legitimate rights of both countries including those in the Aegean Sea. The basic thinking of the Lausanne Treaty was to grant limited areas of maritime jurisdiction to the coastal states and leave the remaining parts of Aegean to the common benefit of Turkey and Greece. Turkey fully respects the provisions of Lausanne and in return expects Greece to act in the same manner. However, Greece have been tilting the Lausanne balance through unilateral acts to the detriment of Turkey's vital interests since 1930's. In other words, Turkish policy is based on respect for the status-quo whereas Greece appears determined to alter it in her favor. The fundamental source of tension between Turkey and Greece is the Greek perception to regard the entire Aegean as a Greek sea in total disregard of Turkey's legitimate rights and vital interests as one of the coastal states.

${ }^{4}$ T.C. Dışişleri Bakanlığı, Enformasyon Dairesi Başkanlığı, "Turkish-Greek Relations / Aegean Problems;" "Background Note on Aegean Dispute;" "Turkey's Aegean Peace Process Initiative;" "Kardak Dispute." 


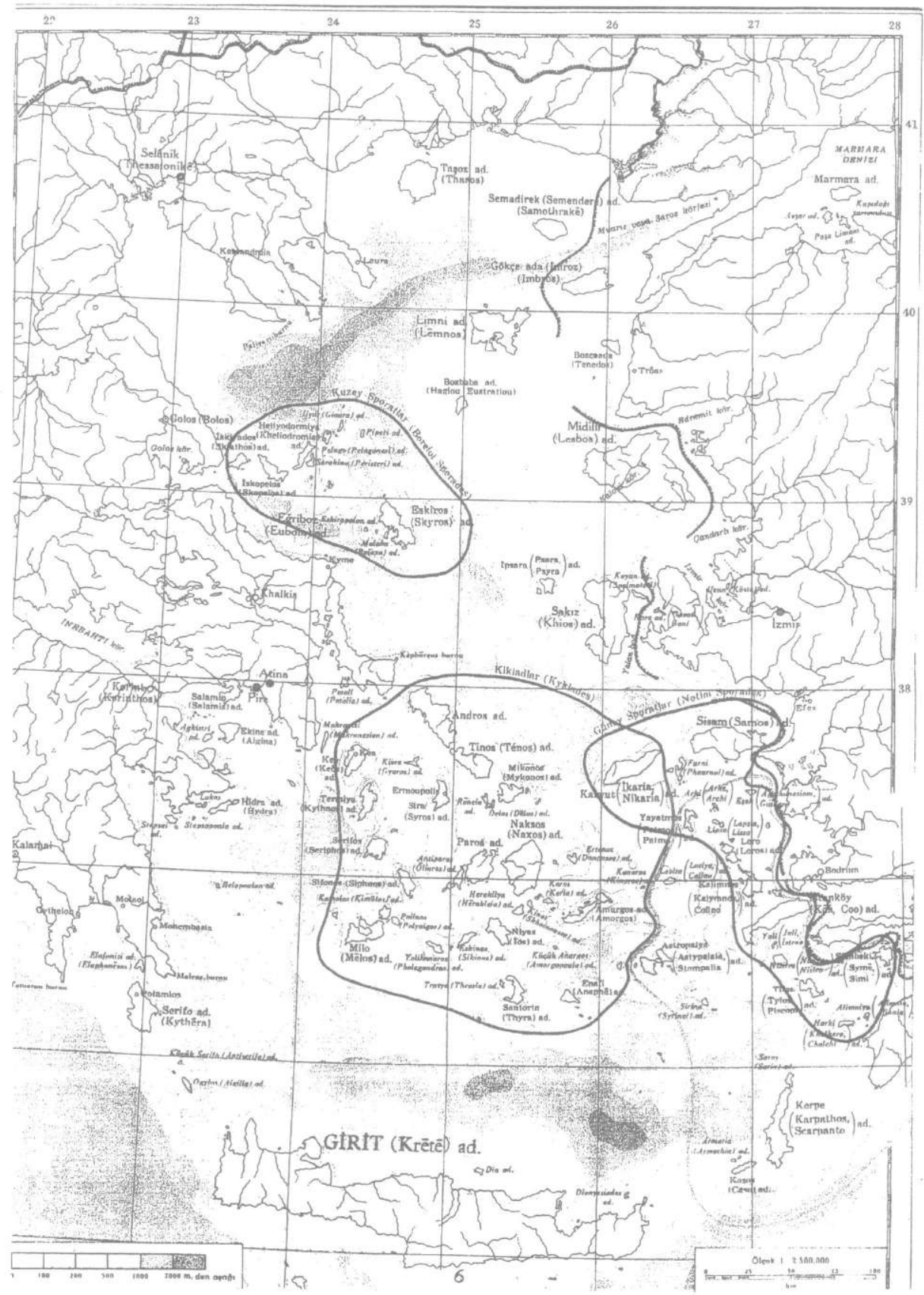

Map 2: Ege Denizi (Adalar Denizi) Aigaion Pelagos 
The Aegean problems can be summarized as follows:

a) The breadth of territorial waters,

b) Delimitation of the continental shelf,

c) Militarization of the Eastern Aegean Islands,

d) Airspace related problems,

e) Islands, islets and rocks in the Aegean which were not ceded to Greece by international treaties.

Most of these longstanding problems could have been resolved years ago had the Greek leadership responded favorably to the repeated Turkish calls for a negotiated settlement and had it abandoned the policy of making use of those disagreements in domestic political power struggles.

\section{Territorial Waters}

Convention on the Law of the Sea (1982) defines the territorial waters as a sea zone between the coasts or the inner waters and the high seas, where the states have the sovereign power. The sovereignty comprises not only the sea zone, but the sea bed and underground as well. According to the same convention, islands have their own territorial waters.

It is stated in the convention that, every state has the right to determine the width of its territorial waters, 12 nautical miles being the upper limit. In other words, the convention has not put a fixed criterion but it has letf the authority to the individual states. The reason why a uniform criterion has not been put is that, some sui generis cases make it impossible to do so.

Aegean Sea, giving no grouns for suspicion, is a sui generis case. Both Turkey and Greece presently exercise a 6 mile breadth of territorial waters in the Aegean which enables almost half of this Sea and the airspace above it being freely used as high seas and international air space by both Turkey and Greece as well as third countries. (Greece extended her territorial waters from 3 miles to 6 miles in 1936, Turkey followed suit in 1964.) 6 miles breadth of territorial waters is therefore directly related to the preservations of vital and legitimate interests of Turkey and Greece in the Aegean and as such constitutes the core of the settlement to every Aegean problem.

Under present 6 mile breadth of the territorial waters, Greece holds approximitely $43,5 \%$ of the Aegean Sea. For Turkey this percentage is 7,5. The remaining $49 \%$ is high seas. The extension by Greece of her territorial waters beyond the present 6 miles in the Aegean will have most inequitable

5 "Law of the Sea," Yearbook of the United Nations 1982, Vol. 36, New York, United Nations Department of Public Information, 1986, p. 178-247. 
implications and would constitute an abuse of right for the following reasons:

a) Such an action will turn the Aegean into a Greek sea to the detriment of Turkey's vital and legitimate interests. In case of an extension, Turkey with 2820 kilometers of coastline on the Aegean Sea will be locked out of the Aegean and confined to her own territorial waters.

Following an extension neither Turkey, nor any other state will be able to benefit from a diminished proportion of high seas in the Aegean for economic, military, navigation and other purposes.

Should the territorial waters be extended to 12 miles as Greece advocates the Greek territorial sea in the Aegean will increase from $43,5 \%$ to $71,5 \%$ whereas Turkey's territorial sea will increase by only $1,2 \%$ (from $7,5 \%$ to $8,7 \%$ ) The area of high seas will therefore reduce from $49 \%$ to $19,7 \%$. (See Map - 3)

The reduced high sea area will also become fragmented due to the linking up of the expanding rings of territorial waters around the Greek islands scattered throughout the Aegean.

In effect Greece will add almost $30 \%$ of the Aegean to her territory and such an expansion will enable this country to have direct control on nearly $3 / 4$ of the entire Aegean Sea.

b) Turkey's access to the high seas will be blocked and her Aegean coast will be encircled by Greek territorial waters.

Under the present 6 mile sea breadth Turkey only has a 126,5 kilometers front on her west coast to the high sea. Should the territorial sea be increased for instance to 12 miles the whole Turkey's coastline to the high sea will be reduced to 11,9 kilometers. Turkey's Aegean coast will therefore be encircled by Greek territorial waters. Even İzmir, Turkey's second largest port will be cut off from the high seas. The routes from the Aegean to the Medeterranean will also pass through Greek territorial waters. Turkey will not be able to enter the high seas without passing through areas under Greek sovereignty and jurisdiction.

c) Turkey's military, economic and scientific interests will be seriously jeopardized.

d) Greece will gain unjustified advantage in delimitation of other maritime jurisdiction areas.

In view of the above, any extension of the territorial sea beyond 6 miles in the Aegean by Greece can not be acceptable to Turkey. Such an extension is also against the provisions (articles 3, 15 and 300) of the 1982 Convention. Therefore, any unilateral action aiming at enlarging maritime 


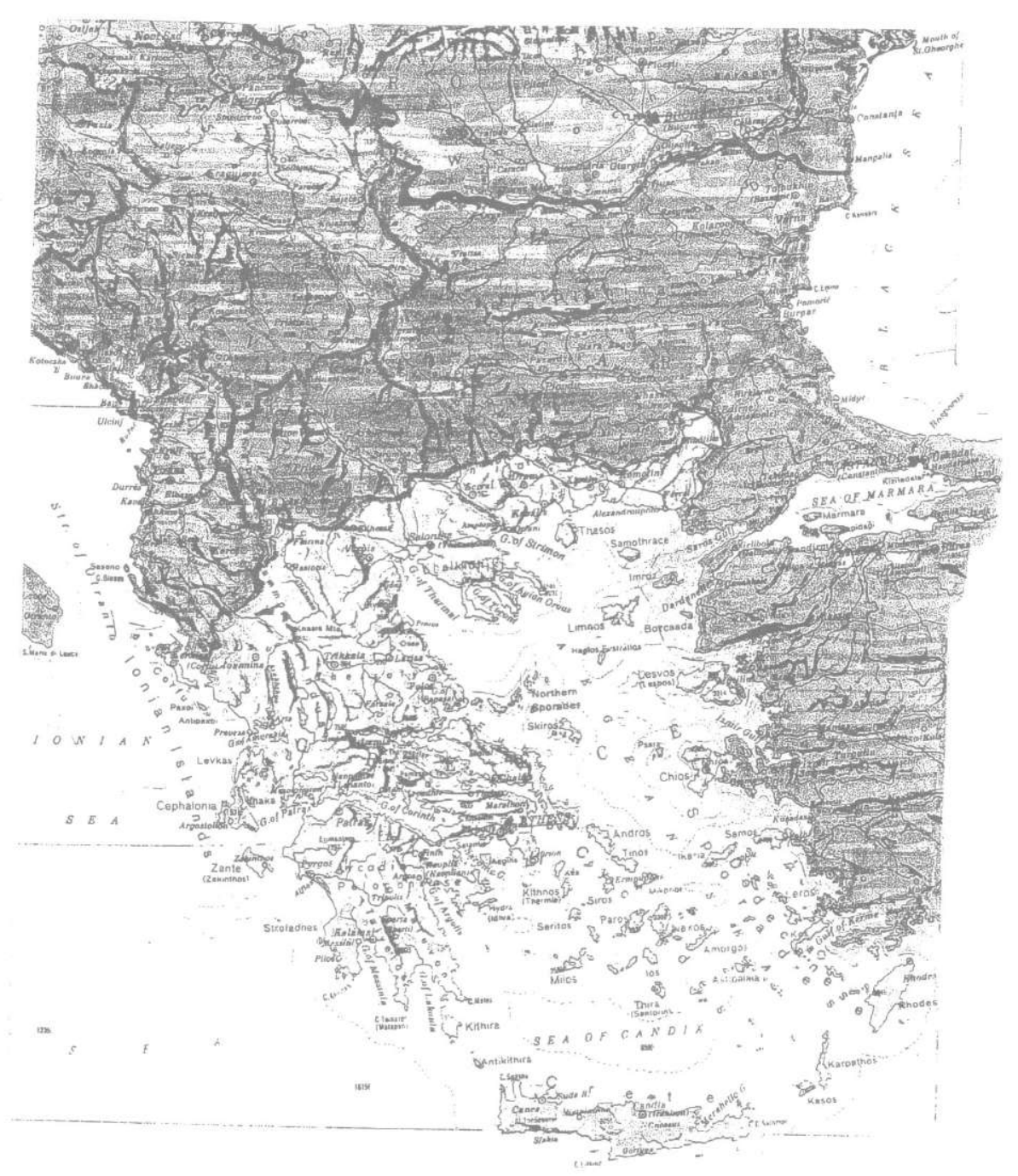

Map 3: Turkish and Greek Shares in the Aegean See if the Territorial Waters arne Ineresesed to 12 Miles 
jurisdiction areas in this Sea should not be allowed for the aforementioned reasons. Turkey has already declared that if Greece would widen her territorial waters such an action will be regarded as casus belli.

In March 1987 Greece under Papaandreu gave to a foreign petroleum company an exploration lisence outside her territorial waters. Turkey warned her neighbour with a note declaring that such provocations would cause retaliation. The warships of the two countries were put out to the Aegean Sea and war was prevented at the very last moment when Greece gave up her exploration attempt.

In December 1988, just after the U.S.A. had widened her territorial waters to 12 miles, Turkey announced that the status of the Aegean Sea was sui generis and the decision of the U.S.A. would not change Turkey's attitude in that Sea. Thereupon the U.S.A. confirmed Turkey's announcement. So Greece held back from widening her territorial waters in the Aegean Sea.

In November 1994, the 1982 Convention on the Law of the Sea has come effective. Greece, with the inclination to seize the opportunity, declared that she has the right to widen her territorial waters in the Aegean Sea to 12 miles. This decleration further increased the tension between the two counties and Turkey performed comprehensive manoeuvres in the Aegean Sea.

In July 1997, both Turkey and Greece have committed themselves to refrain from unilateral acts in the Aegean by the Madrid Decleration. But unfortunately, the E.U. process, especially the Helsinki Decleration of December 1999, has put Turkey in a more disadventageous position against Greece.

\section{Continental Shelf}

The concept of "continental shelf" had been developed when it was noticed that there were rich petroleum and mineral resources under the sea bed. The states who had the technology to operate those riches began to declare sovereign rights unilaterally at the sea- bed adjacent to their seaboards. Thereupon, an international conference was assembled in Geneva in 1958 by the invitation of the United Nations Organization and a convention on the continental shelf was signed there. By that document the coastal states had the right of acquiring continental shelves adjacent to the seaboards of their mainlands and islands to a depth of 200 meters or a distance from their coasts where they had the technical ability to operate the natural resources under the sea-bed. 1958 Convention brought forth new problems 
as the criteria it had been based on were not realistic. ${ }^{6}$ So in 1982 , after a long chain of conferences a new convention was signed in Caracas. ${ }^{7}$

1982 Convention defines the continental shelf as a natural extension of the continent. According to the Convention, coastal states will have the right to acquire continental shelves within which they can use all the natural resources exclusively. The width of the continental shelf will either be to the edge of the continent or 200 nautical miles from the sea-boards if the area of the shallow water exceeds that distance.

The exploration activities under the sea-bed of the Aegean Sea were started by Greece in 1963 and by Turkey in 1968. In 1973 Greece discovered an oilfield within the territorial waters of Thasos (Taşoz) Island. 1973 was a critical year in which the petroleum crisis caused the barrel prices rise up to 10 times of the previous year level. The capacity of the oilfields in Thasos was 25.000 barrels a day, an important quantity. Both Turkey and Greece gave numerous exploration lisences in the Aegean Sea during the following months. Turkish Petroleum Company (T.P.A.O.) considered the middle line of the Aegean Sea as the outer border of the Turkish sovereignty while its Greek counterpart gave its lisences in every part of the Aegean Sea except the Turkish territorial waters. As a result, many exploration lisences had been given for the same exploration areas.

Greece made a formal protest against Turkey and a number of notes having no effect were exchanged. According to the 1982 Convention the coastal states should determine the border between their respective continental shelves by an agreement. But there was not such an agreement then, and yet there is not one today. So the continental shelf dispute stems from the absence of a delimitation agreement effected between the two countries.

In August 1976 when Turkey began to search petroleum under the seabed of the international waters of the Aegean Sea the continental shelf issue once again led the tension between Turkey and Greece. Greece made recourse to both U.N. Security Council and the International Court of Justice. On August 25, 1976 Security Council, in its resolution 395 (1976) called upon the parties "to resume direct negotiations over their differences." On September 11, 1976 the International Court of Justice rejected the Greek application. In conformity with the Security Council decision and in view of the Court rejection of the Greek contention and claims, Turkey and Greece signed an agreement in Bern on November 11, 1976 under which the parties decided to hold negotiations with a view to reaching an agreement on the

${ }^{6}$ Seha L. Meray, Devletler Hukukuna Giriş, C. I, 3. B., Ankara, Ankara Universitesi Siyasal Bilgiler Fakültesi Yay., 1968, p. 617-624.

7 "Law of the Sea," loc.cit. 
delimitation of the continental shelf. They also undertook to refrain from any initiative or act concerning the Aegean Sea. ${ }^{8}$

After the Bern Agreement Turkey and Greece carried on negotiations. But the efforts of Turkey to reach a meaningful solution came to nothing, because "a meaningful solution" was not what Greece wanted. She wanted the Western dominated international organizations or the International Court of Justice force a solution on Turkey which would favor Greece.

In 1981 when Papaandreu came to power and when Greece became a full member of the E.E.C. the negotiations were cut off. Because Greece left the table.

\section{Militarization of the Eastern Aegean Islands}

With the Treaty of Lausanne the Greek sovereignty over the Aegean Islands was confirmed with the exception of the Dodecanese group which was under Italian rule then, and Gökçeada - Bozcaada islands which belonged to Turkey. But this confirmation was attached to the condition of disarmement of the Eastern Aegean Islands. The same condition took place in the Treaty of Paris by which the Dodecanese group was given to Greece.

One of the basic issues between Turkey and Greece in the Aegean Sea is the demilitarized status of the Eastern Aegean Islands. The demilitarization of these islands was due to the overriding importance of them for Turkey's security, a reality which was confirmed both in Lausanne (1923) and Paris (1947).

However Greece, despite the protests of Turkey has been violating the status of the Eastern Aegean Islands by militarizing them since the 1960's in contravention of her contractual obligations. These illegal acts of Greece have increased considerably over the last years and became a vital dispute between the two countries.

\footnotetext{
${ }^{8}$ Aegean Sea Continental Shelf Case (Greece v. Turkey) Request for the Indication of Interim Measures of Protection - Order of 11 September 1976 - International Court of Justice Reports, Lahey, 1976, p. 41; "Dismissal of the Request for the Indication of Interim Measures of Protection," International Court of Justice Background Note VI. Collected Unofficial Summaries of Decisions Concerning the Law of the Sea, 1946 - 1986, Lahey, 1986, p. 59-67.

Solving problems by negotiations is not only an imperative provision of the 1982 Convention but also there are many decisions of the International Court of Justice in the same sense.(North Sea Continental Shelf Cases (Federal Republic of Germany/Denmark; Federal Republic of Germany/Netherlands) Judgement of 20 February 1969, International Court of Justice - Reports of Judgements, Advisory Opinions and Orders, Lahey, 1969; Case Concerning Delimitation of the Maritime Boundary in the Gulf of Maine Area (Canada/U.S.A.) Order of 20 Jan. 1982, International Court of Justice - Reports of Judgements, Advisory Opinions and Orders, Lahey, 1982.)
} 
Greek sovereignty over the Eastern Aegean Islands is now in dispute since this sovereignty was attached to the condition of their disarmement. Vienna Convention about the Law of the Agreements has stated that if a multilateral agreement has not been respected by a participant, any state who suffers from that, has the right to suspend that agreement partly or totally.

\section{Air Space Related Problems}

The core of the conflict is the persistent abuse of "Flight Information Region" (FIR) responsibility by Greece. FIR's were devised by International Civil Aviation Organization in 1950's to provide facilities and services in the international air space due to the increase in the volume of international aircraft movements. FIR arrengements solely entails technical responsibility. It does not change the free status of the air space over the high seas under international law. Greece, however, deliberately misinterprets and abuses her FIR responsibility as if it entails sovereignty over international air space. She considers FIR as a national boundry line.

Imperative provisions of the international law limits the FIR zone with the width of territorial waters. So not any state has the right to widen its FIR zone over the width of its territorial waters. But Greece has proclaimed her FIR zone as 10 miles although the width of her territorial waters is only 6 miles. A 10 mile FIR zone gives Greece the control of $64,1 \%$ of the air space over the Aegean Sea. Turkey, like any other state, refused to acknowledge that illegal proclamation. Greek aircraft constantly intercept and harass Turkish military aircraft over the international air space on the false pretext that they violated Athens FIR by not submitting flight plans. Greek protests on these grounds have repeatedly been rejected by Turkey. ${ }^{10}$

\section{Islands, Islets and Rocks in the Aegean which were not ceded to Greece by International Treaties}

There are numerous small islands, islets and rocks in the Aegean ownership of which were not ceded to Greece by international treaties. Most of those features can not sustain human habitation and have no economic life of their own. Greece attempted to change their status by opening some of those geographical features to artificial settlement.

\footnotetext{
${ }^{9}$ Seha 1. Meray, Lozan Barış Konferansı - Tutanaklar, Belgeler, Ankara, Ankara Üniversitesi Siyasal Bilgiler Fakültesi Yay., C. I/1/1, 1969, p. 96-113; C. II/1/1, 1972, p. 13 26; C. II/2, 1973, p. 6-7, Map No 2; Hüseyin Pazarcı, Doğu Ege Adalarının Askerden Arındırılmış Statüsü, Ankara, Ankara Üniversitesi Siyasal Bilgiler Yay., 1986; Hüseyin Pazarc1, "Has the Demilitarized Status of the Aegean Islands Determined by the Lausanne and Paris Treaties Changed?" Turkish Quarterly Digest, 7 (1986), p. 29-46; Gürel, op.cit., p. 6771; Bilge, loc.cit., p. 10 (22.2.1996).

${ }^{10}$ Gürel, op.cit., p. 78-82.
} 
In November 1995 Greece issued a circular stating that the rocky islands in the Aegean Sea would be improved for touristic purposes. The trap behind those innocent words was that, a few people would be settled on the empty rocky islands of the Aegean Sea in order to put them under Greek sovereignty. Since there are hundrets of uninhabited rocky islands in the Aegean Sea, by this method Greece would be able to reach her aim of making the Aegean a "Greek Lake."

Turkey regarded this new Greek policy as another attempt to establish fait accomplis with a view to close off the Aegean Sea and she made it known for Greece that such initiatives would not produce any effect. At the same time, Turkey began to make a complete land inventory in the Aegean Sea.

The 1996 crisis over the Kardak rocks has erupted by coincidence in such an atmosphere when Greece was making announcements for recruitment of potential settlers from all over the world to some of these islets and rocks.

The Kardak rocks having an area of 400 square meters lie just 3,8 nautical miles off the Turkish coast. The title deed of the rocks are registered on the Karakaya village of Bodrum prefecturate, Muğla province. (See Map - 4) For years Turkish fishermen were engaged in fishing activities on and around these rocks without any hinderence and Turkish vessels have navigated freely through the waters surrounding them.

The series of events started by pure coincidence with the running around of a Turkish bulk carrier named "Figen Akat" near these rocks on 25 December 1995.

On 20 January 1996, nearly a month later, the incident was leaked into the Greek periodical Gramma which is known to be close to the Greek Government. This leak took place only the day after Smitis was named to form the new Greek Government. A media campaign was launched by the Greek press with nationalistic overtones.

Then the major of Kalimnos (Kilimli), a Greek island 5,5 nautical miles away from the Kardak rocks took upon himself to come to the rocks on 26th January and raised the Greek flag. In spite of this provocative action, the official Turkish reaction was very moderate. However, some Turkish journalists, no doubt concerned primarily with the circulation of their paper, hoisted the Turkish flag over Kardak the next day. This flag hoisting competition by individuals could have been considered innocent. But the Greek side had taken a decision to send troops to the Kardak rocks. This was an act of agression against Turkish sovereignty.

On 29 January Greek troops had landed on one of the rocky islands of Kardak. Turkish Government assembled extraordinarily and strongly protested Greece demanding her withdrawal from the Kardak rocks 


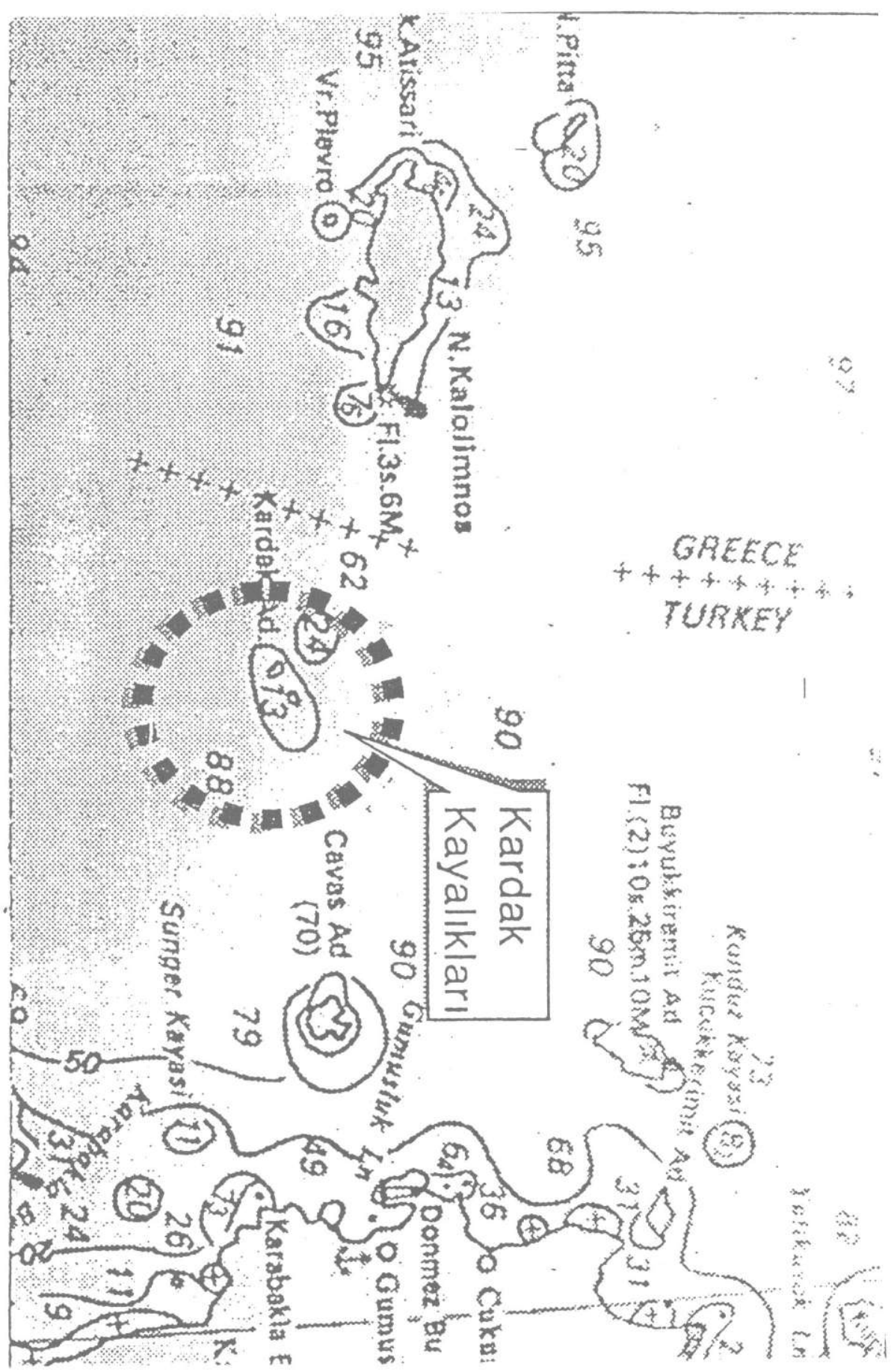

Map 4: World Map Brown by the Greek Department of Hydrographie 
immediately. Turkish and Greek armies at Thrace were put under vigilant state. On the next day, Greek Cypriot army was also put under vigilant state.

At the midnight of 30/31 January Turkish troops landed on the other rocky island of Kardak. Turkish war ships put out to the Aegean Sea. The U.S.A. warned the parties not to go any further.

Turkey and Greece withdrew their troops, dipped their flags and the problem was left to get frozen. ${ }^{11}$ But this was yet another proof of Greece's thirst for territorial expansion beyond areas ceded to her by the Lausanne Peace Treaty of 1923 and the Paris Peace Treaty of 1947.

During and after the Kardak crisis the attitude of the Western World was simply odd. No reaction had come from the West against the Greek occupation of the Kardak rocks. Western World went into a curious silence.

On 29 January, while the Greek troops were occupying the Kardak rocks, Greece made a formal complaint against Turkey in the Council of the E.U. The Council invited the parties not to escalate the crisis although it was obvious that it was Greece who caused the escallation. The U.S. and the Russian Federation proposed moderation to the parties. The attitudes of the Western powers gave the impression that they would tolerate the Greek fait accompli.

When the information about the Turkish landing on the Kardak rocks was received those powers had changed their modes. Clinton telephoned to the leaders of the parties stating that the U.S. would absolutely not tolerate a war in the Aegean Sea.

In February, just after the end of the Kardak crisis, some of the European countries made an announcement declaring that the problems in Europe should be solved within the principles of the E.C.S.C. and they invited Turkey stop threatening Greece.

The Council of the E.U. made a resolution supporting Greece.

European Parliament on the other hand, took a decision on February the 15 th in which Turkey was severely blamed. The decision was taken with 342 votes. Number of the opposing votes were only 21 . In that decision it was claimed that,

a) The Kardak rocks were a part of the Greek territory,

b) The borders of Greece were the borders of the E.U.

In this context, Turkey was blamed for,

1 Cumhuriyet, 15.11.1995 - 1.3.1996; Hürriyet, 15.11.1995 - 1.3.1996; Milliyet, 15.11.1995-1.3.1996. 
a) Breaking the sovereign rights of Greece,

b) Exercising provocative military operations in the Aegean Sea.

Finally, Turkey was invited to approve the pacific settlement of disputes within the provisions of the E.C.S.C. ${ }^{12}$

\section{OTHER PROBLEMS}

Other problems between Turkey and Greece, namely the humanitarian rights of the Turkish minority in Greece and the status of Fener Patriarchate in İstanbul are of less importance when compared to Cyprus and Aegean problems. They are less likely to cause a war between the two countries. It is not because Greece can not provocate them, she certainly can, and in fact she does, directly or indirectly. But the nature of those problems are less convenient for provocation in the present conditions.

\section{CONCLUSION: THE WESTERN QUESTION}

The problems between Turkey and Greece are indeed the problems between Turkey and the West. Although Turkey, as she settled "Westernization" on the axis of her policy, insistently refrains from putting it in this way, this is the case.

Actually, Greece is only an instrument being used against Turkey by the West in order to keep her under control. The question is why it is so important for the West to keep Turkey under control? The answer is simple. Because Turkey with her geographical, historical, social, cultural and military qualifications has a distinguished position in her region. If left to her own devices she may once again become the dominant power in the Middle East, Balkans and Caucasus. In order not to give her that opportunity in such a region of great strategic importance she should be kept under control.

Turkey for her part, is decidedly trying to become a member of the Western structure to save herself from the systematic aggressions of that body. However the West, considering Turkey alien to its edifice, resists her continuous attempts of enterance. During the recent years E.U. has become a test area for this struggle. Turkey hopes to overcome the difficulties she is confronted with. But it is not easy to say that this hope of Turkey depends on realistic grounds. So she should better examine carefully her entire strategic priorities.

${ }^{12}$ European Parliement had depended its decision to a convention and a protocol signed between Turkey and Italy in 1932. However, in the convention the name Kardak (or Imia in Greek) had not been mentioned. The protocol, on the other hand, had never been ratified by the contracting parties.(İsmail Soysal, Tarihçeleri ve Açıklamaları ile Birlikte Türkiye'nin Siyasal Antlaşmaları (1920 - 1945), C. I, Ankara, Türk Tarih Kurumu Yay., 1983, p. 333334; Ferit Hakan Baykal, "Görüş," Cumhuriyet, 12.2.1996, p. 2.) 


\section{BIBLIOGRAPHY}

Books

Gürel, Şükrü Sina, Tarihsel Boyut İçinde Türk Yunan İlişkileri (1821 - 1993), Ankara, Ümit Yay., 1993.

Meray, Seha L., Devletler Hukukuna Giriş, C. I, 3. B., Ankara, A.Ü.S.B.F. Yay., 1968.

$$
\text { Lozan Barış Konferansı - Tutanaklar, Belgeler, C. I/1/1, Ankara, }
$$
A.Ü.S.B.F. Yay., 1969.

A.Ü.S.B.F. Yay., 1972.

C. II/1/1, Ankara,

A.Ü.S.B.F. Yay., 1973.

C. II/2, Ankara,

Pazarcı, Hüseyin, Doğu Ege Adalarının Askerden Arındırılmıs Statüsü, Ankara, A.Ü.S.B.F. Yay., 1986.

Soysal, İsmail, Tarihçeleri ve Açıklamaları ile Birlikte Türkiye'nin Siyasal Andlaşmalart, (1920 - 1945), C. I, Ankara, T.T.K. Yay., 1983.

\section{Articles}

Baykal, Ferit Hakan, “Görüş,” Cumhuriyet, 12.2.1996 - 13.2.1996.

Bilge, Suat, “Atina, Ankara, Lefkoşa Üçgeni,” Cumhuriyet, 18.2.1996 - 24.2.1996.

Pazarc1, Hüseyin, "Has the Demilitarized Status of the Aegean Islands Determined by the Lausanne and Paris Treaties Changed?" Turkish Quarterly Digest, 7 (1986).

\section{Official Publications}

Aegean Sea Continental Shelf Case (Greece v. Turkey) Request for the Indication of Interim Measures of Protection, Order of 11 September 1976, International Court of Justice Reports, Lahey, 1976.

Case Concerning Delimitation of the Maritime Boundary in the Gulf of Maine Area (Canada/U.S.A.), Order of 20 January 1982, International Court of Justice Reports of Judgements, Advisory Opinions and Orders, Lahey, 1982.

"Dismissal of the Request for the Indication of Interim Measures of Protection," International Court of Justice Background Note VI., Collected Unofficial Summaries of Decisions Concerning the Law of the Sea, 1946 - 1986, Lahey, 1986.

"Law of the Sea," Yearbook of the United Nations, 1982, Vol. 36, New York, United Nations Department of Public Information, 1986. 
North Sea Continental Shelf Cases (Federal Republic of Germany / Denmark; Federal Republic of Germany / Netherland) Judgementof 20 February 1969, International Court of Justice - Reports of Judgement, Advisory Opinions and Orders, Lahey, 1969.

T.C. Dışişleri Bakanlığı Enformasyon Dairesi Başkanlığı,

"Cyprus Breefing Note;"

"Turkish - Greek Relations / Aegean Problems;"

"Background Note on Aegean Dispute,"

“Turkey's Aegean Peace Process Initiative,"

"Kardak Dispute."

\section{Newspapers}

Cumhuriyet, 15.11.1996-1.3.1996.

Hürriyet, 15.11.1996 - 1.3.1996.

Milliyet, 15.11.1996 - 1.3.1996. 